\title{
COVID-19 crisis: time to reflect on how we live and interact with nature
}

\author{
Elizabeth Mpofu ${ }^{1}$
}

Accepted: 21 May 2020 / Published online: 10 June 2020

(c) Springer Nature B.V. 2020

Peasant food systems are crucial to building defence against crises.

\section{What do we stand for and why?}

I need to state from the onset that we as La Via Campesina, our fight is for food systems based on traditional knowledge and peasant agroecology. It is fighting for our century's old way of life that is in harmony with nature and produces healthy food for people. For us to defend this way of life has meant that we struggle for our rights to land and territory, seeds, biodiversity and natural resources to keep producing healthy food for the present and future. Our political goal is to achieve Food Sovereignty, which aims to strengthen and rebuild our local food systems and shape a new model of economic and social relations based on dignity, solidarity and ethics.

\section{Why are we vulnerable to not just the COVID-19 but any new diseases?}

We are what we eat.

It is common knowledge that this first line of defence of our bodies against pathogens, our immune system, depends on the food we eat. The thinner the diet, the more vulnerable and weaker are our bodies to fight off pathogens. It implies that the more extensive our food diversity, the stronger and healthier we become. However, the current globalised industrial food system, which is founded on homogeneity to maximise profits, does not concur with such a reality. The nutrient sources from this production system are narrow and

This article is part of the Topical Collection: Agriculture, Food \& Covid-19.

Elizabeth Mpofu

eliz.mpofu@gmail.com

1 Harare, Zimbabwe thus inadequate to build effective and robust body defence mechanisms. We must press upon the fact that many people are vulnerable to COVID-19 precisely because of the poor diets (we call this the junk food which is causing many health conditions such as diabetes, high blood pressure, overweight, respiratory challenges etc.). Now is the time to reinforce local quality food production and consumption and make it available to all. We call upon our governments and institutions to protect peasant production, local markets, to support and protect farm and migrant workers.

\section{Where and how did we stray?}

One thing is sure. The crises (ecological, economic, climate) we are living through are a product of "greed" for profit. The current dominant financial system, capitalism, has been and is excessively exploiting and extracting more out of both labour and nature for profit. Many people have dispossessed of their territories to make a way of profitdriven land uses. The relationship between people (humanity) and the environment has broken and urgently needs to be repaired before it's too late. A few wealthy individuals (elites), literary own everything and control our governments. They have used their wealth to shape public policies in their favour. For instance, the Agricultural, seed, food distribution and financing policies mostly favour transnational agribusinesses. Peasant food systems face neglect. This why we see increasing protests because of economic inequality, poverty and climate crisis which can no longer be tolerated. We need our governments to put people at the centre of all their policies, not profits!

\section{What is the solution to healthy, diverse foods for healthier bodies?}

As La Via Campesina, we know that the peasants produce over $70 \%$ of food consumed globally. We, therefore, call on the governments to urgently put in policies to support these 
communities. In this sense, improving infrastructure in the countryside, increasing the availability, accessibility and sustainability of food, facilitating access to rural financial services, such as credit and financing, would allow investment in agroecological production, promoting increased productivity of land and labour. It means recognising, promoting and protecting the rights of peasant farmers and agriculture workers. It is essential to guarantee Peasant Rights, as stated in the UN Declaration of the Rights of Peasants and other People working in the Rural Areas approved by the United Nations in 2018. We need land, seeds, water and all the conditions to feed the populations safely. It is what peasants urgently need in this coronavirus crisis and beyond. Lastly, during this coronavirus pandemic, as in all situations, solidarity is crucial.

Publisher's Note Springer Nature remains neutral with regard to jurisdictional claims in published maps and institutional affiliations.
Elizabeth Mpofu, Harare Zimbabwe. Date of birth: 30 December 1959, Zimbabwe. Elizabeth Mpofu is an organic farmer and an activist based in Shashe, Masvingo. She has dedicated her life to work tirelessly for the betterment of smallholder farmers and women rights in general. Elizabeth has held various leadership positions since 1990. Currently she is a member of the International coordination committee (ICC) and the General Coordinator of LA VIA Campesina, an international peasants' movement with a membership of over 200 million farmers from about 164 local and national organizations in 73 countries from Africa, Asia, Europe and the Americas. She is a founder member of two important farmer organisations, one at national level and the other at regional. She was designated at UN FAO Special Ambassador for the International Year of Pulses in 2016. At national level she helped to establish Zimbabwe Smallholder Organic Farmers Forum (ZIMSOFF) which promotes organic farming. At regional level she founded with others the Eatern Southern Smallholder Farmers Forum (ESAFF) which promotes sustainable farming practices. Currently she chairs the ZIMSOFF and Association of Traditional and Environmental Conservationist (AZTREC) Boards and a steering committee member of Alliance for Food Sovereign Africa (AFSA). She presided as chairperson of ESAFF from 2004 to 2011, later became vise chairperson in 2012-2013 and now a Board Member. 